\title{
Leakage Compositional Changes Accompanying to exposure of some Mango Cultivars to Low Temperature under Field Conditions
}

\author{
Farouk M. Gadallah, Mohamed A. Seif El-Yazal, \\ Gamal A. Abdel-Samad and Ali A. S. Sayed* \\ Botany Department, Faculty of Agriculture, Fayoum University, Fayoum 63514, Egypt
}

A B S T R A C T

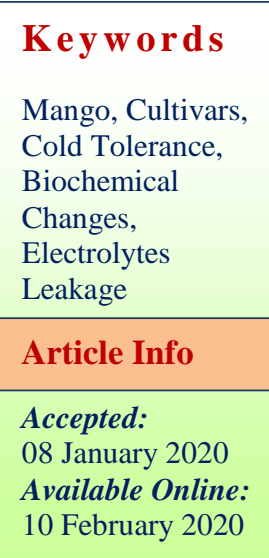

Keywords

Mango, Cultivars,

Cold Tolerance,

Biochemical

Electrolyte

akage

Accepted:

08 January 2020

10 February 2020
Under invivo conditions (ambient-air temperature), the relationship between low temperature stress and the response of some different mango cultivars was monitored. Some biochemical events that occur following cold exposure of mango trees leaves were detected to evaluate their ability to acquire cold injury during exposure to low temperature. The cultivars of Alphonso, Baladi, Bullock's Heart, Helmand, Hindi Besennara, Mabrouka, Mestekawy, Nabeeh, Oweisi, Spates, Taimour and Zebda which grown in private orchard in Fayoum Governorate, Egypt were selected to verify this aim. This study was carried out during the period from November to March of during years; 2012 and 2013. The following results were stated: the detected leaf compositional changes were significantly differed among the tested cultivars and sampling times. In this respect, electrolytes $(\%), \mathrm{Na}^{+}, \mathrm{K}^{+}$, inorganic phosphate $\left(\mathrm{P}_{\mathrm{i}}\right), \mathrm{Ca}^{2+}$, total soluble sugars (TSS) and total free amino acids (TFAA) concentrations were detected in leachate of fresh leaves and showed significant differences in response to the cultivars and sampling times. However, in this study, Alphonso, Bullock's Heart, Helmand, Taimour and Zebda cultivars of mango had the best result in their cold tolerance under the conditions of this study, which is not exactly in consistent with what the researcher found.

\section{Introduction}

Mango (Mangifera indica L.) is a popular, nutritional tropical fruit, which is now one of the most important fruits crops in tropical and subtropical areas of the world (Mitra and Baldwin, 1997). Mango occupies third place in total world production of major tropical fruit crops after citrus and banana (Alonso and Blaikie, 2003). Environmental conditions outside the traditional areas for optimum growth of mango may impose stresses, which can result in physiological changes, reduced growth, or even permanent damage to the trees (Schaffer et al., 1994). Low temperature is acknowledged to be one of the most dominant environmental stresses that affect the growth, productivity and geographical distribution of crops and horticultural plants (Boyer, 1982). Exposure to low, nonfreezing temperatures induces genetic, morphological, metabolic and physiological changes in 
plants, which result in the development of cold hardiness and acquisition of freezing tolerance (Huner et al., 1993). Mango needs an optimum temperature range of $24-26.7^{\circ} \mathrm{C}$ and minimum threshold temperature is 10 $12^{\circ} \mathrm{C}$ below this plant shows chilling injury (Allen and Ort, 2001) and show high susceptibility to low temperature $\left(0-15^{\circ} \mathrm{C}\right)$.

Young trees are damaged by low temperature variability among cultivars is apparent after a cold spell, but precise information on this subject is non-existent (Farooq and Azam, 2002). Electrolyte leakage is widely used to measure chilling damage as well as to quantity species resistance to cold and chilling injury (Mckay, 1992). Such conductivity measurements have also been used to estimate the positive permeability of membranes to electrolytes (Piotrowska and Kacperska, 1987). Sugars and some of the cold-induced proteins are suspected to have cryoprotective effects; they stabilize proteins and membranes during dehydration induced by low temperature (Taiz and Zeiger, 1998).

In cold tolerant tissues, the protective function of sugars has been ascribed to their ability to stabilize membranes and proteins during cold (freeze) induced dehydration (Minorsky, 2003). Little is known about seasonal changes in soluble carbohydrates in both of xylem and park tissues, including whether the type and or concentration of specific sugars differ depending on how the tissues are adapted to cooling or freezing (Kasuga et al., 2007).

It has been reported that under natural conditions, soluble sugars increase during the onset of winter when plants are subjected to low temperatures; conversely, soluble sugars decrease in spring when plants are deacclimating (Siminovitch, 1981). Chilling of plants leads to an increase in inorganic $\mathrm{P}$ content and a drop in the proportion of organic P (Zia et al., 1994) which is a consequence of a breach of phosphorylation and enhanced decomposition of organic $\mathrm{P}$ compounds. Calcium is considered to be an important factor for the maintenance of cell membrane integrity and the regulation of ion transport. $\mathrm{Ca}^{2+}$ ions are essential for $\mathrm{K}^{+}$vs. $\mathrm{Na}^{+}$ion selectivity and membrane integrity (Hanson, 1984).

Cold stress induces transient $\mathrm{Ca}^{2+}$ influx into the cytoplasm. Therefore, calcium permeable channels responsible for this $\mathrm{Ca}^{2+}$ influx are considered as sensors for low temperature (Monroy and Dindsa, 1995). They suggested that $\mathrm{Na}^{+}$ions acted by displacing $\mathrm{Ca}^{2+}$ ions from membranes, leading to increased membrane permeability and higher intracellular $\mathrm{Na}^{+}$ions concentrations. Cytoplasmic calcium levels increase rapidly in response to low temperature, largely due to an influx of calcium from extracellular stores (Polisensky and Braam, 1996).

Solutes $\left(\mathrm{Ca}^{2+}, \mathrm{Na}^{+}, \mathrm{K}^{+}\right.$ions) leak from the leaves of chill sensitive, but not from those of chill resistant. Loss of solutes to water reflects damage to the plasma membrane and possibly also the tonoplast (Taiz and Zeiger, 1998). (Kafkafi, 1990). The effects of the high $\mathrm{K}^{+}$ content of the cell in increasing frost tolerance have also been related to regulation of osmotic and water potential of the cell sap and reduction of electrolyte leakage caused by chilling temperature (Singer et al., 1996). In response to cold and other osmotic stresses, plants accumulate a range of compatible (Osmolytes) solutes including soluble sugars, amino acids (Ruelland and Zachowski, 2010).

The metabolism of nitrogenous compounds is also responsive to low-temperature stress (Usadel et al., 2008), in particular that of certain amino acids and polyamine compounds (Davey et al., 2009). Factors implicated in cold acclimation include expression of cold-stress proteins (Hughes 
and Dunn, 1996), accumulation of sugars, particularly sucrose (Strand et al., 2003), other cryoprotectans, such as proline (Bravo et al., 2001). Changes in water soluble carbohydrates (Leborgne et al., 1995), or in free amino acids, especially proline (Xin and Browse 1998), are associated with cold acclimation and acquisition of cold tolerance. The positive correlation between the accumulation of endogenous proline and improved cold tolerance has been found mostly in low temperature-insensitive plants such as barley, grapevine, potato and chickpea (Kaur et al., 2011).

Thus, check some putative biochemical events that occur following cold exposure and Evaluation of some mango cultivars (grown under Fayoum Governorate conditions) according to resistance to these events were aimed.

\section{Materials and Methods}

In a private orchard, Fayoum, Egypt, located at $29^{\circ} 22^{\prime} \mathrm{N}$ and $30^{\circ} 47^{\prime} \mathrm{E}$. and in the laboratory of Agricultural Botany Dept., Faculty of Agric., Fayoum University. A trial was conducted during 2012 and 2013. The experiment assess to evaluate the cold tolerance of some mango cultivars grown in the orchard and check the leaf compositional changes that occur following cold exposure.

\section{Climate of experiment site}

At the site of experiment, temperatures fluctuated during the duration of study and five years before the beginning of the study. In this respect, the mean monthly maximum temperature $\left(\mathrm{T}_{\text {Max }}\right)$ ranging from about $17.7^{\circ} \mathrm{C}$ in January 2008 to about $40.2^{\circ} \mathrm{C}$ in August 2010 and the fluctuation in mean monthly minimum temperature $\left(\mathrm{T}_{\text {Min }}\right)$ was ranging from about $5.7^{\circ} \mathrm{C}$ in January 2007/2008 to about $25.2^{0} \mathrm{C}$ in August 2012. An extreme minimum temperature of $0.6^{0} \mathrm{C}$ was recorded in January 2008; however, there were large differences between the selected years (Table $1)^{*}$.

\section{Plant materials}

The plant materials comprised 12 mango cultivars which collected from their natural growing location in the period of November 2012 to march 2013. This is approximately the time at which the cold hardiness may be occurring. Mango trees were about 25 years old, planted in a clay soil at $5 \times 5 \mathrm{~m}$ apart. The cultivars were used in this study including most of the popular cultivars which grown in Fayoum Governorate. The tested cultivars were, Alphonso, Baladi, Bullock's Heart, Helmand, Hindi Besennara, Mabrouka, Mestekawy, Nabeeh, Oweisi, Spates, Taimour, and Zebda.

Thirty-six trees of similar phenotype in the field (size, vigor...etc.) and with management prehistory were selected for this experiment (no further tests were carried out confirm genetic uniformity). All selected trees were allocated at random with each replicate. The trees were derived from seedlings; named Baladi, while the others they had been grafted onto seedling rootstocks. To obtain a complete picture of mango cold tolerance status under natural conditions, measurements must be made at frequent intervals throughout the growth period. Therefore, samples of ten mature terminal fully expanded leaves (similar development ages) were randomizedly taken from each tree (as a replication) at $30^{\text {th }}$ of each month from November to March. Leaves were collected (between 9 am to $10 \mathrm{am}$ ) from one-year-old shoots of the mango cultivars and used as a plant material. All treatments were applied in a factorial randomized complete block design with three replicates. 
Table.1 The monthly mean of maximum and minimum temperatures (open air-temperature) during the period from January 2006 to March 2013

\begin{tabular}{|c|c|c|c|c|c|c|c|c|c|}
\hline Month Year & Temp. & 2006 & 2007 & 2008 & 2009 & 2010 & 2011 & 2012 & 2013 \\
\hline \multirow{2}{*}{ January } & Max. & 19.4 & 19.4 & 17.7 & 20.7 & 21.9 & 20.7 & 20.4 & 23.0 \\
\hline & Min. & 6.6 & 5.7 & 5.7 & 6.7 & 7.6 & 8.0 & 7.2 & 10.3 \\
\hline \multirow{2}{*}{ February } & Max. & 22.2 & 21.4 & 20.0 & 22.3 & 24.4 & 22.0 & 22.4 & 24.3 \\
\hline & Min. & 8.4 & 7.8 & 6.5 & 6.4 & 8.2 & 9.4 & 8.2 & 10.4 \\
\hline \multirow{2}{*}{ March } & Max. & 26.3 & 25.0 & 28.6 & 23.2 & 27.5 & 25.6 & 25.4 & 29.0 \\
\hline & Min. & 9.7 & 9.8 & 11.6 & 7.9 & 11.4 & 9.5 & 11.8 & 12.6 \\
\hline \multirow{2}{*}{ April } & Max. & 30.4 & 28.6 & 31.6 & 30.8 & 31.8 & 28.5 & 29.1 & \\
\hline & Min. & 13.3 & 12.5 & 13.7 & 12.5 & 14.3 & 13.7 & 13.6 & \\
\hline \multirow{2}{*}{ May } & Max. & 33.4 & 35.2 & 35.4 & 32.8 & 34.1 & 32.8 & 34.1 & \\
\hline & Min. & 16.9 & 17.7 & 18.2 & 16.7 & 16.7 & 17.4 & 18.3 & \\
\hline \multirow{2}{*}{ June } & Max. & 36.5 & 39.3 & 39.4 & 38.2 & 38.4 & 35.7 & 38.4 & \\
\hline & Min. & 20.0 & 20.7 & 22.0 & 20.4 & 21.4 & 20.6 & 21.8 & \\
\hline \multirow{2}{*}{ July } & Max. & 37.4 & 38.9 & 37.7 & 38.5 & 36.3 & 38.7 & 39.8 & \\
\hline & Min. & 21.3 & 21.8 & 22.1 & 22.7 & 22.4 & 21.5 & 23.6 & \\
\hline \multirow{2}{*}{ August } & Max. & 38.3 & 37.8 & 38.6 & 37.0 & 40.2 & 38.6 & 38.0 & \\
\hline & Min. & 22.1 & 21.7 & 22.2 & 21.8 & 24.5 & 22.9 & 25.2 & \\
\hline \multirow{2}{*}{ September } & Max. & 34.8 & 34.3 & 35.9 & 35.2 & 36.2 & 36.1 & 35.2 & \\
\hline & Min. & 20.3 & 20.5 & 20.0 & 20.7 & 21.9 & 22.1 & 23.4 & \\
\hline \multirow{2}{*}{ October } & Max. & 31.0 & 32.1 & 31.5 & 31.7 & 35.9 & 30.2 & 34.4 & \\
\hline & Min. & 17.2 & 18.3 & 17.2 & 18.1 & 21.3 & 17.7 & 22.2 & \\
\hline \multirow{2}{*}{ November } & Max. & 23.6 & 26.7 & 26.6 & 25.0 & 31.3 & 26.5 & 27.9 & \\
\hline & Min. & 11.1 & 12.8 & 13.1 & 11.7 & 16.5 & 12.6 & 16.4 & \\
\hline \multirow{2}{*}{ December } & Max. & 19.9 & 21.3 & 22.2 & 22.4 & 24.1 & 22.0 & 21.8 & \\
\hline & Min. & 7.5 & 8.2 & 9.1 & 8.9 & 10.3 & 9.7 & 11.0 & \\
\hline
\end{tabular}

* Data applied by Bureau of Meteorology, Agriculture Ademonstratrions, Fayoum Governorate, Egypt.

\section{Electrolytes leakage (\%) estimation}

The total leakage of inorganic ions was estimated (Lutts et al., 1996). Fresh leaf samples were cut into equal sized pieces $(1 \mathrm{~g}$ replicate $^{-1}$ ). Each sample was placed in boiling glass bottle $(100 \mathrm{ml}$ brown glass bottle) containing $50 \mathrm{ml}$ deionized water. Bottles were then incubated at $25^{\circ} \mathrm{C}$ in an incubator for 24 hours, and then the electrical conductivity of the solution was recorded using a conductivity meter $\mathrm{EC}_{1}$ (Mod: HI99300).

The bottles were then boiled at $100^{\circ} \mathrm{C}$ for 7 min, and re-incubated at $25^{\circ} \mathrm{C}$ in an incubator for 24 hours, and then the electrical conductivity of the solution was recorded $\mathrm{EC}_{2}$. Electrolyte leakage (\%) was calculated using the following formula:EL $(\%)=\left(\mathrm{EC}_{1} /\right.$ $\left.\mathrm{EC}_{2}\right) \times 100$

\section{Total soluble sugars determination}

Soluble sugars in leakage $\left(\mathrm{mg} 100 \mathrm{~g}^{-1} \mathrm{FW}\right)$ were determined based on phenolsulfuric acid method by (Dubois et al., 1956). A glucose was used to standardize the procedure for quantifying sample values.

\section{Total free amino acids determination}

Total free amino acids in leakage $\left(\mathrm{mg} 100 \mathrm{~g}^{-1}\right.$ FW) were determined calorimetrically 
according to (Jayarman, 1981). To determine the content of total free amino acids in each fresh leaf sample, a standard curve was done based on arginine.

\section{Elements $\left(\mathrm{K}^{+}, \mathrm{Na}^{+}\right.$and $\left.\mathbf{P}_{\mathbf{i}}\right)$ determination}

In leakage, $\mathrm{Na}^{+}$and $\mathrm{K}^{+}$concentration (ppm) was determined by using flamephotometer (Gallenkamp CO., England) (Page et al., 1982).

$\mathrm{Pi}$ concentraion $\left(\mathrm{mg} 100^{-1} \mathrm{~g} \quad \mathrm{FW}\right)$ was colorimetrically estimated by using chlorimetrically estimated by using chlorostonnous molybdophospheric blue colour method in sulfuric acid system as described by Jackson (1967).

\section{Calcium determination}

A titration with ethylene diamine tetra acetate (EDTA) method is that of Diehl et al., (1950), was used for calcium determinationin leakage $\left(\mathrm{mg} 100^{-1} \mathrm{~g} \mathrm{FW}\right)$ as described by the U.S. salinity Laboratory (1954), U.S.D.A. Handbook 60.

\section{Statistical analysis}

All data were subjected to analysis of variance (ANOVA) using the statistical software package of Genstat (version 11) (VSN International Ltd., Oxford, UK). Means comparison among the different treatments were performed using the least significant differences procedure (LSD) at the $P \leq 0.05$ level as illustrated by Snedecor and Cochran (1980).

\section{Results and Discussion}

The results of one season were discussed because no significant differences were observed between results of the studied seasons.

Table.2 Electrolytes (\%) in leachate of mango leaves at various sampling dates (November to March) under field conditions.

\begin{tabular}{|l|l|l|l|l|l|l|}
\hline \multirow{2}{*}{ Cultivars } & \multicolumn{9}{|l}{ **ampling date* (Month) } \\
\cline { 2 - 7 } & Nov. & Dec. & Jan. & Feb. & Mar. & Mean \\
\hline Alphonso & 30.20 & 31.55 & 39.59 & 55.31 & 28.29 & $\mathbf{3 6 . 9 9}$ \\
\hline Baladi & 31.10 & 30.54 & 22.93 & 37.54 & 28.44 & $\mathbf{3 0 . 1 1}$ \\
\hline Bullock's Heart & 35.41 & 36.58 & 30.27 & 41.63 & 31.42 & $\mathbf{3 5 . 0 6}$ \\
\hline Helmand & 35.08 & 43.10 & 29.33 & 28.73 & 21.90 & $\mathbf{3 1 . 6 3}$ \\
\hline Hindi Besennara & 43.09 & 45.97 & 46.13 & 41.03 & 30.66 & $\mathbf{4 1 . 3 8}$ \\
\hline Mabrouka & 38.34 & 33.05 & 33.61 & 40.70 & 31.57 & $\mathbf{3 5 . 4 5}$ \\
\hline Mestekawy & 33.02 & 42.15 & 30.68 & 23.94 & 34.78 & $\mathbf{3 2 . 9 1}$ \\
\hline Nabeeh & 30.92 & 44.68 & 34.19 & 38.33 & 25.48 & $\mathbf{3 4 . 7 2}$ \\
\hline Oweisi & 29.39 & 39.07 & 31.42 & 26.83 & 27.06 & $\mathbf{3 0 . 7 6}$ \\
\hline Spates & 33.54 & 44.33 & 34.89 & 37.03 & 32.42 & $\mathbf{3 6 . 4 4}$ \\
\hline Taimour & 37.13 & 37.85 & 38.19 & 43.87 & 34.06 & $\mathbf{3 8 . 2 2}$ \\
\hline Zebda & 28.96 & 46.69 & 32.24 & 30.16 & 43.09 & $\mathbf{3 6 . 2 3}$ \\
\hline Mean & $\mathbf{3 3 . 8 5}$ & $\mathbf{3 9 . 6 3}$ & $\mathbf{3 3 . 6 2}$ & $\mathbf{3 7 . 0 9}$ & $\mathbf{3 0 . 7 6}$ & \\
\hline LSD $(\mathbf{5} \%)$ & A & $\mathbf{2 . 2 4}$ & & & & \\
\hline & B & $\mathbf{3 . 4 7}$ & & & & \\
\hline A x B & $\mathbf{7 . 7 7}$ & & & & \\
\hline
\end{tabular}

$\mathrm{A}=$ Sampling date $\mathrm{B}=$ Cultivars

$\mathrm{AxB}=$ Sampling date $\mathrm{x}$ Cultivars

*Each value represents the mean of three replicates **The sample was taken at the end of each month. 


\section{Electrolytes leakage (\%)}

The results in Table (2) indicates that the changes in Electrolytes leakage (EL, \%) were differed according to the cultivar and sampling times. It's clear that the highest value of EL (\%) was exhibited by Hindi Besennara cultivar in November month. The cultivar of Zebda was found to has the highest value of EL (\%) as a compared by the others, while the lowest value was recorded by Baladi cultivar in December month, the EL (\%) recorded by the cultivar of Hindi Besennara was the highest and by Baladi cultivar was the lowest in January month.

In February month, the greatest value was given by Alphonso cultivar and the lowest one was recorded by the cultivar of Mestekawy. At the end of experiment, in March month, the highest value of
Electrolytes (\%) was exhibited by Zebda cultivar and the lowest one by Helmand cultivar. However, the EL (\%) was significantly differed among the cultivars during the whole sampling times. Since the cultivar of Hindi Besennara recorded the highest value of EL (\%) and the lowest one was given by Baladi cultivar. The effect of sampling times was absorved. The sampling time of December recorded the highest value and the lowest one was exhibited by the sample of March.

\section{Analysis of leakage}

\section{Total Soluble Sugars (TSS)}

Data in Table (3) show that TSS reached its peak level by Helmand cultivar but the lowest level of TSS at November month was recorded by Nabeeh cultivar.

Table.3 Total soluble sugars ( $\left.\mathrm{mg} 100 \mathrm{~g}^{-1} \mathrm{FW}\right)$ in leachate of mango leaves at various sampling dates (November to march) under field conditions.

\begin{tabular}{|c|c|c|c|c|c|c|}
\hline \multirow{2}{*}{ Cultivars } & \multicolumn{6}{|c|}{$* *$ Sampling date* (Month) } \\
\hline & Nov. & Dec. & Jan. & Feb. & Mar. & Mean \\
\hline Alphonso & 31.89 & 30.51 & 36.05 & 31.20 & 30.16 & $\mathbf{3 1 . 9 6}$ \\
\hline Baladi & 45.41 & 35.01 & 16.64 & 24.27 & 27.73 & $\mathbf{2 9 . 8 1}$ \\
\hline Bullock's Heart & 48.19 & 39.52 & 24.27 & 15.95 & 22.53 & $\mathbf{3 0 . 0 9}$ \\
\hline Helmand & 54.08 & 47.49 & 27.04 & 22.19 & 23.23 & $\mathbf{3 4 . 8 1}$ \\
\hline Hindi Besennara & 27.04 & 22.19 & 14.91 & 30.16 & 24.27 & $\mathbf{2 3 . 7 1}$ \\
\hline Mabrouka & 22.53 & 19.41 & 20.11 & 27.04 & 23.92 & $\mathbf{2 2 . 6 0}$ \\
\hline Mestekawy & 26.35 & 22.19 & 23.23 & 20.80 & 21.15 & $\mathbf{2 2 . 7 4}$ \\
\hline Nabeeh & 20.45 & 12.83 & 13.52 & 14.56 & 18.03 & $\mathbf{1 5 . 8 8}$ \\
\hline Oweisi & 47.15 & 54.43 & 20.80 & 37.44 & 34.67 & $\mathbf{3 8 . 9 0}$ \\
\hline Spates & 25.65 & 27.39 & 33.97 & 22.88 & 44.03 & $\mathbf{3 0 . 7 8}$ \\
\hline Taimour & 41.25 & 18.03 & 16.99 & 43.33 & 44.72 & $\mathbf{3 2 . 8 6}$ \\
\hline Zebda & $\mathbf{5 1 . 3 1}$ & 35.01 & 36.75 & 16.99 & 30.16 & $\mathbf{3 4 . 0 4}$ \\
\hline Mean & $\mathbf{3 6 . 7 8}$ & $\mathbf{3 0 . 3 3}$ & $\mathbf{2 3 . 6 9}$ & $\mathbf{2 5 . 5 7}$ & $\mathbf{2 8 . 7 2}$ & \\
\hline LSD $(\mathbf{5 \% )}$ & $\mathbf{A}$ & & & $\mathbf{4 . 2 2}$ & & \\
\hline & B & & & $\mathbf{6 . 5 3}$ & \\
\hline
\end{tabular}


The maximum level of TSS in December sample was exhibited by Oweisi cultivar and the lowest by Nabeeh one. In January, the cultivar of Zebda showed the highest value of TSS, while the greater value was recorded by Nabeeh cultivar. In addition, the level of TSS reached to its maximum by the cultivar of Taimour and the minimum by Nabeeh one.

But in March, the cultivar of Helmand recorded the highest value of TSS in leachates of leaves with the lowest level of Nabeeh one. However, TSS level was significantly differed among the cultivars during the all sampling times. In this respect, Oweisi cultivar gave the highest value and the lowest one was given by Nabeeh cultivar. Regarding, the effect of sampling time, November month sample recorded the greatest value of TSS and the lowest one was given by the sample in January. Generally, the level of TSS was significantly differed among the sampling times of the studied cultivars.

\section{Total free amino acids (TFAA)}

The data in Table (4) indicate the differences in TFAA level among the studied cultivars under the field condition. In this respect, Taimour cultivar showed the highest value in TFAA level as compared to the others, while the lowest value was recorded by Mabrouka cultivar in November sample. The cultivar of Hindi Besennara showed a higher level of TFAA than those recorded by the others in December month and the lowest one was obtained by Mestekawy cultivar. It is also clear that the level of TFAA was the highest by Alphonso cultivar and the lowest was recorded by Mestekawy one in January month.

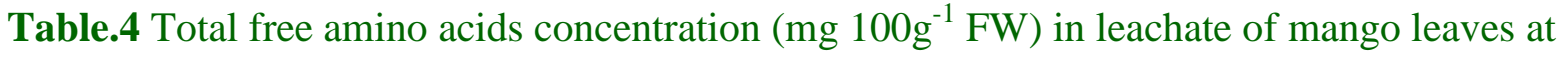
various sampling dates (November to march) under field conditions

\begin{tabular}{|c|c|c|c|c|c|c|}
\hline \multirow{2}{*}{ Cultivars } & \multicolumn{7}{|c|}{ **Sampling date } \\
\hline & Nov. & Dec. & Jan. & Feb. & Mar. & Mean \\
\hline Alphonso & 22.38 & 17.14 & 24.28 & 24.76 & 24.28 & 22.57 \\
\hline Baladi & 17.62 & 19.52 & 18.57 & 26.66 & 18.57 & 20.19 \\
\hline Bullock's Heart & 20.00 & 18.09 & 16.19 & 12.86 & 20.00 & 17.43 \\
\hline Helmand & 20.00 & 17.62 & 17.14 & 17.14 & 13.33 & 17.05 \\
\hline Hindi Besennara & 19.52 & 27.14 & 19.05 & 20.95 & 18.09 & 20.95 \\
\hline Mabrouka & 15.71 & 18.57 & 23.33 & 36.66 & 34.28 & 25.71 \\
\hline Mestekawy & 25.24 & 15.71 & 16.66 & 57.14 & 20.47 & 27.04 \\
\hline Nabeeh & 18.57 & 22.38 & 16.66 & 23.33 & 19.52 & 20.09 \\
\hline Oweisi & 16.19 & 17.62 & 18.09 & 20.47 & 16.66 & 17.81 \\
\hline Spates & 17.14 & 20.95 & 14.28 & 16.66 & 17.62 & 17.33 \\
\hline Taimour & 31.90 & 19.05 & 19.05 & 23.33 & 20.47 & 22.76 \\
\hline Zebda & 15.71 & 16.66 & 15.24 & 18.57 & 14.28 & 16.09 \\
\hline Mean & 20.00 & 19.20 & 18.20 & 24.90 & 19.80 & \\
\hline LSD $(5 \%)$ & $\mathbf{A}$ & & & $\mathbf{4 . 7 5}$ & & \\
\hline & $\mathbf{B}$ & & & & \\
\hline
\end{tabular}


When the sampling time was lengthened, at February month, the TFAA level was the highest by Mestekawy cultivar as a compared to the others, while the lowest value was recorded by Bullock's Heart cultivar. At the end of experiment, at March month, the highest value of TFAA was recorded by Mabrouka cultivar and the lowest by Helmand one. However, TFAA was significantly differed among the cultivars during the all sampling times. Since Mestekawy cultivar gave the highest value of TFAA and the lowest by Zebda cultivar. Regarding, the effect of sampling time, at February month sample, recorded the highest level of TFAA and the lowest one was given by the sample in January month. Generally, the level of TFAA was significantly differed among the sampling times of the tested cultivars.

\section{Sodium $\left(\mathrm{Na}^{+}\right)$}

Relative leakage of sodium $\mathrm{Na}^{+}$from Mango leaves of the different cultivars is shown in Table (5). It's obvious that the amount of leached $\mathrm{Na}^{+}$in November month was maximal from leaves of Alphonso cultivar than those of the others. However, the lowest value was given by the leaves of Oweisi and Zebda cultivars. In December month, the greatest amount of leached $\mathrm{Na}^{+}$was exhibited by Hindi Besennara cultivar, while the lowest one was recorded by Alphonso cultivar. In addition, the quantity of leached $\mathrm{Na}^{+}$reached its maximum by the cultivar of Zebda and the minimum by Mabrouka one in January month, but in February month, the cultivar of Oweisi recorded the highest value of leached $\mathrm{Na}^{+}$with the lowest value of Mestekawy cultivar.

Table.5 Concentration of $\mathrm{Na}^{+}(\mathrm{ppm})$ in leachate of mango leaves at various sampling dates (November to march) under field conditions

\begin{tabular}{|c|c|c|c|c|c|c|}
\hline \multirow[t]{2}{*}{ Cultivars } & \multicolumn{6}{|c|}{ **Sampling date* (Month) } \\
\hline & Nov. & Dec. & Jan. & Feb. & Mar. & Mean \\
\hline Alphonso & 6.61 & 2.05 & 2.99 & 2.99 & 2.99 & 3.53 \\
\hline Baladi & 3.78 & 2.83 & 2.83 & 3.46 & 4.41 & 3.46 \\
\hline Bullock's Heart & 6.14 & 5.67 & 2.83 & 3.62 & 2.83 & 4.22 \\
\hline Helmand & 3.31 & 2.83 & 3.78 & 4.41 & 3.78 & 3.62 \\
\hline Hindi Besennara & 5.20 & 7.09 & 3.31 & 3.78 & 3.94 & 4.66 \\
\hline Mabrouka & 4.72 & 3.62 & 2.36 & 2.83 & 4.88 & 3.69 \\
\hline Mestekawy & 4.25 & 4.41 & 3.31 & 2.68 & 3.78 & 3.69 \\
\hline Nabeeh & 2.83 & 2.83 & 3.15 & 4.41 & 3.94 & 3.43 \\
\hline Oweisi & 2.36 & 2.52 & 3.46 & 6.14 & 6.14 & 4.13 \\
\hline Spates & 6.14 & 2.36 & 2.83 & 2.99 & 2.83 & 3.43 \\
\hline Taimour & 5.20 & 4.72 & 3.15 & 4.41 & 2.99 & 4.09 \\
\hline Zebda & 2.36 & 2.52 & 4.25 & 3.94 & 4.72 & 3.56 \\
\hline Mean & 4.41 & 3.62 & 3.19 & 3.81 & 3.94 & \\
\hline \multirow[t]{3}{*}{$\operatorname{LSD}_{(5 \%)}$} & $\mathbf{A}$ & \multicolumn{5}{|c|}{0.39} \\
\hline & B & \multicolumn{5}{|c|}{0.60} \\
\hline & $A \times B$ & \multicolumn{5}{|c|}{1.34} \\
\hline
\end{tabular}


In March month, the greatest amount of leached $\mathrm{Na}^{+}$was given by Oweisi cultivar and the lowest ones were recorded by Bullock's Heart and Spates cultivars. However, leached $\mathrm{Na}^{+}$was significantly differed among the cultivars during the sampling times. In this respect, Hindi Besennara cultivar gave the highest and the lowest ones were given by Nabeeh and Spates cultivars. Regarding, the effect of sampling time, November moth sample recorded the highest value of leached $\mathrm{Na}^{+}$and the lowest one was given by the sample in January. Generally, the level of $\mathrm{Na}^{+}$ efflux was significantly differed among the sampling time of the tested cultivars.

\section{Potassium $\left(\mathrm{K}^{+}\right)$}

The results in Table (6) clearly show that the changes in potassium $\left(\mathrm{K}^{+}\right)$efflux into the external medium (distilled water) were differed according to the cultivars and the sampling times. It's clear that the maximum leakage of $\mathrm{K}^{+}$was obtained from the leaves of Zebda cultivar and minimum value by Mabrouka one in November month. The cultivar Helmand was found to has the greatest value of leaked $\mathrm{K}^{+}$as a compared by the others, while the lowest value was given by the cultivars of Mabrouka, Oweisi and Zebda in December month.

In January month, the cultivar of Helmand recorded the highest value of leaked $\mathrm{K}^{+}$and the lowest one was given by the cultivars of Mabrouka, Oweisi and Taimour. In February month, the greatest value was recorded by Helmand cultivar and the lowest one by the cultivar of Baladi. At the end of experiment, in March month, the highest value of leaked $\mathrm{K}^{+}$was exhibited by Zebda cultivar and the lowest one by Baladi and Taimour cultivars.

Table.6 Concentration of $\mathrm{K}^{+}$(ppm) in leachate of mango leaves at various sampling dates (November to march) under field conditions

\begin{tabular}{|l|l|l|l|l|l|l|}
\hline \multirow{2}{*}{ Cultivars } & \multicolumn{2}{|l}{ *Sampling date* (Month) } & & \\
& Nov. & Dec. & Jan. & Feb. & Mar. & Mean \\
\hline Alphonso & 6.98 & 2.99 & 1.74 & 3.49 & 1.99 & $\mathbf{3 . 4 4}$ \\
\hline Baladi & 5.48 & 2.74 & 2.58 & 1.91 & 1.74 & $\mathbf{2 . 8 9}$ \\
\hline Bullock's Heart & 5.98 & 2.99 & 1.91 & 2.49 & 2.49 & $\mathbf{3 . 1 7}$ \\
\hline Helmand & 7.81 & 3.99 & 3.90 & 4.49 & 2.74 & $\mathbf{4 . 5 9}$ \\
\hline Hindi Besennara & 9.47 & 2.49 & 1.99 & 2.99 & 2.49 & $\mathbf{3 . 8 9}$ \\
\hline Mabrouka & 4.49 & 2.99 & 1.25 & 3.49 & 2.49 & $\mathbf{2 . 9 4}$ \\
\hline Mestekawy & 8.47 & 2.99 & 1.50 & 3.99 & 3.49 & $\mathbf{4 . 0 9}$ \\
\hline Nabeeh & 9.47 & 2.41 & 2.16 & 2.49 & 2.91 & $\mathbf{3 . 8 9}$ \\
\hline Oweisi & 8.47 & 2.24 & 1.25 & 3.49 & 2.24 & $\mathbf{3 . 5 4}$ \\
\hline Spates & 4.98 & 3.99 & 1.50 & 2.74 & 1.99 & $\mathbf{3 . 0 4}$ \\
\hline Taimour & 6.98 & 2.24 & 1.25 & 2.99 & 1.74 & $\mathbf{3 . 0 4}$ \\
\hline Zebda & 9.97 & 2.24 & 1.99 & 1.99 & 3.99 & $\mathbf{4 . 0 4}$ \\
\hline Mean & $\mathbf{7 . 3 8}$ & $\mathbf{2 . 8 6}$ & $\mathbf{1 . 9 2}$ & $\mathbf{3 . 0 5}$ & $\mathbf{2 . 5 3}$ & \\
\hline LSD $(5 \%)$ & $\mathbf{A}$ & $\mathbf{0 . 2 0}$ & & & & \\
\hline & $\mathbf{B}$ & $\mathbf{0 . 3 1}$ & & & & \\
\hline & $\mathbf{A} \mathbf{x}$ B & $\mathbf{0 . 7 0}$ & & & & \\
\hline
\end{tabular}

$\mathrm{A}=$ Sampling date $\mathrm{B}=$ Cultivars $\mathrm{AxB}=$ Sampling date $\mathrm{x}$ Cultivars

*Each value represents the mean of three replicates

**The sample was taken at the end of each month. 
Moreover, the leaked $\mathrm{K}^{+}$was significantly differed among the cultivars during the whole sampling times. Since the cultivar of Helmand recorded the highest value of leaked $\mathrm{K}^{+}$and the lowest one was given by Baladi cultivar. The effect of sampling times was observed.

The sampling time of November recorded the highest value and the lowest one was exhibited by January month. In general, the leaked $\mathrm{K}^{+}$level was significantly differed among sampling times of the studied cultivars.

\section{Inorganic phosphate $\left(\mathbf{P}_{\mathrm{I}}\right)$}

Relative $\mathrm{P}_{\mathrm{I}}$ Leakage from leaves of the different cultivars of Mango is shown in Table (7). It's evident that the amount of leached PI reached to its maximal by
Alphonso cultivar but the minimal was observed by Helmand one. The maximum amount of leached PI in December sample was exhibited by Spates cultivar and the lowest one was recorded by Bullock's Heart cultivar. In January, the cultivar of Bullock's Heart given the highest value of leached PI and lowest one was observed by Helmand cultivar. In addition, the value of PI reached to its maximum by the cultivar of Bullock's Heart and minimum by Mestekawy one in February month. But in March, the cultivar Zebda recorded the highest value of leached PI in leachate of leaves with the lowest value by Nabeeh one. However, leached PI value was significantly differed among the cultivars throughout the all sampling times. In this respect, Bullock's Heart cultivar gave the highest value and the lowest one was given by Helmand cultivar.

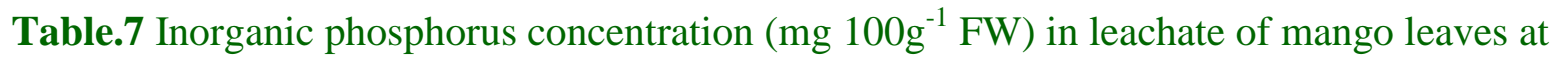
various sampling dates (November to march) under field conditions

\begin{tabular}{|c|c|c|c|c|c|c|}
\hline \multirow[t]{2}{*}{ Cultivars } & \multicolumn{6}{|c|}{ **Sampling date* (Month) } \\
\hline & Nov. & Dec. & Jan. & Feb. & Mar. & Mean \\
\hline Alphonso & 13.09 & 8.81 & 10.59 & 11.66 & 6.31 & 10.09 \\
\hline Baladi & 7.85 & 7.73 & 9.16 & 11.66 & 6.66 & 8.62 \\
\hline Bullock's Heart & 8.45 & 5.35 & 14.52 & 16.78 & 8.69 & 10.76 \\
\hline Helmand & 4.52 & 6.07 & 4.88 & 11.30 & 6.19 & 6.59 \\
\hline Hindi Besennara & 5.71 & 9.76 & 12.85 & 7.73 & 7.38 & 8.69 \\
\hline Mabrouka & 7.14 & 7.73 & 8.21 & 12.73 & 7.97 & 8.76 \\
\hline Mestekawy & 6.31 & 8.81 & 6.07 & 6.78 & 7.38 & 7.07 \\
\hline Nabeeh & 4.88 & 7.73 & 5.24 & 15.59 & 5.83 & 7.85 \\
\hline Oweisi & 8.57 & 8.57 & 12.73 & 12.97 & 7.38 & 10.04 \\
\hline Spates & 8.21 & 10.95 & 5.95 & 11.07 & 8.45 & 8.92 \\
\hline Taimour & 6.43 & 7.85 & 5.59 & 11.90 & 6.31 & 7.62 \\
\hline Zebda & 5.95 & 5.95 & 10.00 & 12.38 & 10.11 & 8.88 \\
\hline Mean & 7.26 & 7.94 & 8.82 & 11.88 & 7.39 & \\
\hline \multirow[t]{3}{*}{$\operatorname{LSD}_{(5 \%)}$} & $\mathbf{A}$ & \multicolumn{5}{|l|}{0.55} \\
\hline & B & \multicolumn{5}{|l|}{0.85} \\
\hline & $A \times B$ & \multicolumn{5}{|l|}{1.89} \\
\hline
\end{tabular}


Regarding, the effect of sampling time, February month sample recorded the greatest value leached PI and the lowest one was given by November month. Generally, the level of leached PI was significantly differed among the sampling times of the tested cultivars.

\section{Calcium $\left(\mathrm{Ca}^{2+}\right)$}

It's evident from data presented in Table (8) that there is a cultiveral differences the amount of leached $\mathrm{Ca}^{+2}$ from Mango leaves during the sampling times. In this respect, the cultivar of Taimour was found to has the highest value of leached $\mathrm{Ca}^{+2}$, while the lowest value was recorded by Bullock's Heart cultivar in November month. The highest value of leached $\mathrm{Ca}^{+2}$ from leaves, in December month, was observed to be the highest by the cultivar of Mestekawy and the lowest one by Nabeeh.In January, the highest value was recorded by Zebda cultivar and the lowest by Helmand one. In February month, the cultivar of Oweisi was exhibited the highest value of leached $\mathrm{Ca}^{2+}$ and the lowest by Nabeeh cultivar. Also, Taimour cultivar gave the highest value and Bullock's Heart cultivar recorded the lowest one in March month. However, the amount of leached $\mathrm{Ca}^{2+}$ was significantly differed among the cultivars during the whole sampling times, since the cultivar of Hindi Besennara shown the highest value and Bullock's Heart cultivar gave the lowest one. Regarding, the effect of sampling time; March month sample exhibited the highest value of leached $\mathrm{Ca}^{+2}$ and the lowest was noticed by the sample in December month. Generally, the value of leached $\mathrm{Ca}^{2+}$ was significantly differed among the sampling times of the tested cultivars.

Table.8 Concentration of $\mathrm{Ca}^{+2}\left(\mathrm{mg} \mathrm{g}^{-1} \mathrm{FW}\right)$ in leachate of mango leaves at various sampling dates (November to march) under field conditions

\begin{tabular}{|c|c|c|c|c|c|c|}
\hline \multirow[t]{2}{*}{ Cultivars } & \multicolumn{6}{|c|}{ **Sampling date* (Month) } \\
\hline & Nov. & Dec. & Jan. & Feb. & Mar. & Mean \\
\hline Alphonso & 9.67 & 8.33 & 6.33 & 12.67 & 10.00 & 9.40 \\
\hline Baladi & 9.00 & 5.00 & 4.67 & 2.67 & 18.67 & 8.00 \\
\hline Bullock's Heart & 3.67 & 4.33 & 7.67 & 10.33 & 4.67 & 6.13 \\
\hline Helmand & 8.00 & 6.67 & 4.33 & 5.67 & 13.00 & 7.53 \\
\hline Hindi Besennara & 5.33 & 7.67 & 11.67 & 12.00 & 22.00 & 11.73 \\
\hline Mabrouka & 5.67 & 5.67 & 6.67 & 14.67 & 6.67 & 7.87 \\
\hline Mestekawy & 5.67 & 10.00 & 7.67 & 7.00 & 9.67 & 8.00 \\
\hline Nabeeh & 4.00 & 2.67 & 12.67 & 2.33 & 8.67 & 6.07 \\
\hline Oweisi & 12.00 & 4.00 & 8.67 & 18.00 & 14.00 & 11.33 \\
\hline Spates & 6.00 & 8.67 & 7.33 & 11.00 & 9.33 & 8.47 \\
\hline Taimour & 16.00 & 7.67 & 6.00 & 8.67 & 18.33 & 11.33 \\
\hline Zebda & 13.33 & 7.67 & 16.00 & 8.00 & 6.67 & 10.33 \\
\hline Mean & 8.19 & 6.53 & 8.31 & 9.42 & 11.81 & \\
\hline \multirow{3}{*}{$\operatorname{LSD}_{(5 \%)}$} & A & \multicolumn{5}{|l|}{2.45} \\
\hline & B & \multicolumn{5}{|l|}{3.79} \\
\hline & $A \times B$ & \multicolumn{5}{|l|}{8.47} \\
\hline
\end{tabular}


Table. 8 Concentration of $\mathrm{Ca}^{+2}\left(\mathrm{mg} \mathrm{g}^{-1} \mathrm{FW}\right)$ in leachate of mango leaves at various sampling dates (November to march) under field conditions.

\begin{tabular}{|c|c|c|c|c|c|c|}
\hline \multirow[t]{2}{*}{ Cultivars } & \multicolumn{6}{|c|}{ **Sampling date* (Month) } \\
\hline & Nov. & Dec. & Jan. & Feb. & Mar. & Mean \\
\hline Alphonso & 9.67 & 8.33 & 6.33 & 12.67 & 10.00 & 9.40 \\
\hline Baladi & 9.00 & 5.00 & 4.67 & 2.67 & 18.67 & 8.00 \\
\hline Bullock's Heart & 3.67 & 4.33 & 7.67 & 10.33 & 4.67 & 6.13 \\
\hline Helmand & 8.00 & 6.67 & 4.33 & 5.67 & 13.00 & 7.53 \\
\hline Hindi Besennara & 5.33 & 7.67 & 11.67 & 12.00 & 22.00 & 11.73 \\
\hline Mabrouka & 5.67 & 5.67 & 6.67 & 14.67 & 6.67 & 7.87 \\
\hline Mestekawy & 5.67 & 10.00 & 7.67 & 7.00 & 9.67 & 8.00 \\
\hline Nabeeh & 4.00 & 2.67 & 12.67 & 2.33 & 8.67 & 6.07 \\
\hline Oweisi & 12.00 & 4.00 & 8.67 & 18.00 & 14.00 & 11.33 \\
\hline Spates & 6.00 & 8.67 & 7.33 & 11.00 & 9.33 & 8.47 \\
\hline Taimour & 16.00 & 7.67 & 6.00 & 8.67 & 18.33 & 11.33 \\
\hline Zebda & 13.33 & 7.67 & 16.00 & 8.00 & 6.67 & 10.33 \\
\hline Mean & 8.19 & 6.53 & 8.31 & 9.42 & 11.81 & \\
\hline \multirow[t]{3}{*}{$\mathbf{L S D}_{(5 \%)}$} & $\mathbf{A}$ & \multicolumn{5}{|c|}{2.45} \\
\hline & B & \multicolumn{5}{|c|}{3.79} \\
\hline & $A \times B$ & \multicolumn{5}{|c|}{8.47} \\
\hline
\end{tabular}

\section{Discussion}

Chilling temperatures (lower than $15^{\circ} \mathrm{C}$ ) lead to numerous physiological disturbances in the cells of chilling-sensitive plant and result in chilling injury and death of tropical and subtropical (Lukatkin et al., 2012). Obviously, the problem of plant resistance to chilling temperature, which often occurs in spring and autumn in many countries, is important for practical plant breeding. A change in the Egyptian climate has already been observed during the last decades, and this is expected to continue throughout this century. This change in climate affects the behavior of fruit trees and their productivity. In 2008, Egypt was exposed to a wave of frost that caused severe damage to mango trees; Hence, there is a need to know which cultivars are resistant to winter cold (Ismail, 2014).

As a result of this sensitivity, low temperature produce a range of physiological and metabolic disorders that lead to serious losses. The various dysfunctions that arise under low temperature conditions result in various physical and metabolic changes that are easily scored and which can therefore be used to assess the degree of chilling injury. Thus, the objective of this trail is to study the some of physiological changes as indicators for determine index of some mango cultivars and to know which of them are resistant to chilling temperatures. In this respect, the following physiological indices were detected. Electrolytes leakage is widely used to measure chilling damage as well as to quantity species resistance to cold and chilling injury in conifer (Mckay, 1992) and in apple (Suwapanich and Haesungcharoen, 2006).

Low temperature alters the physical properties of cell membranes. Chilling of sensitive plants leads to multiple changes in their 
membranes, which enhance permeable properties of cell membrane (Lukatkin et al., 2012). These changes in the state of membranes may lead to secondary of irreversible reactions, depending on temperature, exposure duration and sensitivity of the species (or cultivars).

After a prolonged chilling, these changes will cause loss of membrane integrity and compartmentation, the leakage of solutes, decrease of oxidative activity of mitochondria, increase of the activation energy of membrane-bond enzymes including $\mathrm{H}+$-ATPase, reduce the rate of photosynthesis, cause disruption and imbalance of metabolism, the accumulation of toxic substances and the symptoms of chilling injury (Kasamo et al., 2000). In addition, A number of species of tropical have the lateral phase separation temperature some higher $\left(15^{\circ} \mathrm{C}\right)$ than in plants from temperate zones $\left(6-8^{\circ} \mathrm{C}\right)$ suggesting that plants reduce the freezing point of membranes with the distance from zone of tropical origin (Terzaghi et al., 1989).

However, the increased leakage of electrolytes from the cultivar of HindyBesennara (Table 2) was interpreted as resulting from deteriorative changes in membranes and corresponds to the presence of released inorganic and organic ions. Similar results were obtained by Chinnusamy et al., (2007). Whereas ion uptake in plants receives considerable attention, the release of solutes from the plant into the environment is less investigated. Considerable amounts of solutes are lost after cell damage and cell death. In this respect, the basic assumption is that the greater the injury of the living tissue, the greater the efflux of ions from stressed cells (Palta et al., 1977).

A maximal level of $\mathrm{Na}^{+}$leakage was observed by the cultivar of HindyBesennara (Table 3 ).
The differences in the rate of $\mathrm{Na}^{+}$efflux among these leaves of different cultivars reflect actual differences in membrane permeability and have protective effect on membrane damage. Thus, may be attributed to the cultivars had lower $\mathrm{Na}^{+}$content in the tissues resulted in lesser damage to the cells.

These results are in accordance with those of Taiz and Zeiger (1998) who found that $\mathrm{Na}^{+}$ ions leak from the leaves of chill sensitive more than those of chill resistant. Loss of $\mathrm{Na}^{+}$ to water reflects damage to the plasma membrane and possibly also the tonoplast. The leakage of $\mathrm{K}^{+}$from the leaves into the imbibing medium was differed between the tested cultivars under the condition of field. The highest rate of $\mathrm{K}^{+}$efflux was observed at the leaves of Helmand (Table 3 ) this, reflects the impairment of membrane under environmental stress.

It is also clear from data in Table (4) that, the amount of leaked $\mathrm{K}^{+}$was similar to that of leaked $\mathrm{Na}^{+}$at field conditions. Thus, may be attributed to the cultivars had lower $\mathrm{K}^{+}$ content in the tissues resulted in lesser damage to the cells. Similar results had found by (Taiz and Zeiger, 1998). Relative Pi leakage as a function of the conditions of field recorded the highest values of leached Pi from leaves of Bullock's heart (Table 5). This increased leakage with these cultivars suggests a marked damage to the membrane which limits leakage from tissues.

Also, the origin of $\mathrm{Pi}$ could be from decomposition of different phosphatecontaining metabolites and structural components by various phosphatases and subsequent leaching of Pi under cold stress. These results are in a good agreement with those reported by Taiz and Zeiger (1998). Leaf electrolytes values of $\mathrm{Ca}^{2+}$ in Table (6) indicate that Nabeehcultivar are more resistant to leakage of $\mathrm{Ca}^{2+}$ than the others. 
Increased resistance to cold stress in these cultivars may occur as a result of the role of $\mathrm{Ca}^{2+}$ in conforming cold resistance (Percival et al., 1999). $\mathrm{Ca}^{2+}$ is involved in the control and maintenance of physiological plant responses to chilling injury such as the maintenance of membrane integrity and transport function (Palta, 1996). Additionally, cold stress induces transient $\mathrm{Ca}^{2+}$ permeable channels for this $\mathrm{Ca}^{2+}$ influx are considered as sensors for low temperature (Monroy and Dindsa, 1995).

The activation of $\mathrm{Ca}^{2+}$ channels by cold is thought to the result of physical alterations in cellular structure. Previous studies had the same trends (Catala et al., 2003). Differential rates of total soluble sugars (TSS) leakage had developed in response to the conditions of field (Table 7). Maximum leakage of TSS was obtained by from the leaves of Ewais. While, the lowest values were recorded by the cultivar of Nabeeh.

This trend reflects the membrane dysfunction with chilling sensitive cultivars to the conditions of study more than the tolerant ones. It has been reported that under natural conditions, TSS increase during the onset of winter when plants are subjected to low temperatures; conversely, decrease in spring when plants are deacclimating (Sauter et al., 1996). These results are similar to those obtained by Lennartsson and Ögren (2004). Relative leakage of total free amino acids (TFAA) from the collected leaves from the field explained that the loss of TFAA in the leakage of the cultivar of Zebda more than others (Table 8) may be associated with loss of membrane integrity. This result is in good agreement with that obtained by Ghosh et al., (1981).

\section{References}

Allen D J and Ort D R.2001.Impacts of chilling temperatures on photosynthesis in warm climate plants.Trends in Plant Science6:3642.

Alonso G and Blaikie S J.2003. Seasonal variation of carbonassimilation in mango (cv. Kensington Pride): effect offlowering treatments. Australian Journal of Agriculture Research54:309-321.

Boyer J S.1982.Plant productivity and environment.Science 218:443-448.

Bravo L A, Ulloa N, Zuniga G E, Casanova A, Corcuera L J and Alberdi M.2001.Cold resistance in Antarctic angiosperms.Plant Physiol.111:55-65.

Catala R, Santos E, Alonso J M, Ecker J R, Martinez-Zapater $\mathrm{J} \quad \mathrm{M}$ and Salinas J.2003.Mutations in the $\mathrm{Ca}^{2+} / \mathrm{H}^{+}$transporter CAXl increase $C B F / D R E B 1$ expression and the cold-acclimation response in Arabidopsis. Plant Cell15:2940-2951

Chinnusamy V, Zhu J and Zhu J K.2007. Cold stress regulation of gene expression in plants. Trends in Plant Science10(12):244251.

Davey M P, Woodward F I and Quick W P.2009.Intraspecific variation in coldtemperature metabolic phenotypes of Arabidopsis lyratassp. Petraea.Metabolomics5:138-149.

Diehl H, Goetz C A and Hach C C.1950.The versenate titration for total hardness.Journal of the American Water Works Association 42:40-48.

Dubois M, Gilles K, Hamilton J, Rebers P and smith F.1956.Colormetric method for determination of sugars and related substances.Analytical chemistry28(3):350356.

Farooq S and Azam F.2002.The Co-existence of salt and drought tolerance in Triticaceae.Hereditas, 135:205-210.

Ghosh B, Adhikary J and Banerjee N C.1981.Changes of some metabolites in rice seeds during ageing.Seed Science and Technology 9(2):469-473.

Hanson J B.1984.The function of calcium in plant nutrition, pp149-208.In: advances in plant nutrition. Vol.1, Tinker P B and Lauchi A (Eds). Praeger, New York, USA.

Hughes M A and Dunn M A.1996.The molecular biology of plant acclimation to low temperature.Journal of Experimental 
Botany 47:291-305.

Huner N P A, ÖquistG, Hurry V M, KrolM, Falk $S$ and Griffith M.1993. Photosynthesis, Photoinhibition and low temperature acclimationin cold tolerant plants. Photosynthesis Research 37:19-39.

Ismail O M.2014.Use of electrical conductivity as a tool for determining damage index of some mango cultivars.International Journal of Plant \& Soil Science3(5): 448-456.

Jackson M L.1967.Soil Chemical Analysis, pp144179.New Delhi, Prentice Hall of India private Limited, New Delhi, India.

Jaradat, AA and Rinke J L.2010. Nutrient homeostasis, C:N:S ratios, protein, and oil content in Cuphea seed. Seed Science and Biotechnology4(1)1-9.

Jayarman J. 1981.Laboratory Manual in Biochemistry, pp61-73.Wiley Eastern Ltd., New York, USA.

Kafkafi U.1990.The functions of plant $K^{+}$in overcoming environmental stress situations, pp81-93.In: Proc. $22^{\text {nd }}$ colloquium of IPI,held in Soligorsk, USSR, IPI, Bern.

Kasamo K, Yamaguchi $M$ and Nakamura Y.2000.Mechanism of the chilling-induced decrease in proton pumping across the tonoplast of rice cells.Plant and Cell Physiology41(7):840-849.

Kasuga J, Arakawa K and Fujikawa S.2007.High accumulation of soluble sugars in deep supercooling Japanese white birch xylem parenchyma cells.New Phytologist174:569579.

Kaur G, Kumar S, Thakur P, Malik J A, Bhandhari K, Sharma K D and Nayyar H.2011. Involvement of proline in response of chickpea (Cicerarietinum L.) to chilling stress at reproductive stage. ScientiaHorticulturae 128(3):174-181.

LAHaye P A and Epstein E.1969.Salt toleration by plants: enhancement with Calcium. Science 166:395-396.

Leborgne N, Teulieres C, Travert S, Rols M P,Teissie $J$ and Boudet A M.1995. Introduction of specific carbohydrates into Eucalyptusgunniicells increases their freezing tolerance. European Journal of Biochemistry229:710-717.

Lennartsson $M$ and Ögren E.2004: Clonal variation in temperature requirements for budburst and dehardening in Salix species used for biomass production. Scandinavian Journal of Forest Research 19:295-302.

LukatkinA S, Brazaityte A, Bobinas C, DuchovskisP.2012. Chilling injury in chilling-sensitive plants: a review. Žemdirbystè-Agriculture 99(2):111-124.

Lutts S, Kiner J M and Bouharmont J.1996. NaCl induced senescence in leaves of rice cultivars differing in salinity resistance. Annals of Botany78:389-398.

Mckay H.1992.Electrolyte leakage from fine roots of conifer seedlings: A rapid index of plant vitality following cold storage. Canadian Journal of Forest Research22:1371-1377.

Minorsky P V.2003. Raffinose oligosaccharides.Plant Physiology131:1159-1160.

Mitra S K and Baldwin E A.1997.Mango.pp85122. Mitra S K (Ed), Postharvest physiology and storage of tropical and subtropical fruits. CAB International. New York, USA.

Monroy A Fand Dhindsa R S.1995.Lowtemperature signal transduction: induction of cold acclimation specific genes of alfalfa by calcium at $25^{\circ} \mathrm{C}$. Plant Cell, 7(3):321331.

Page A I, Miller R H, and Keeny D R. 1982.Methods of Soil Analysis, pp225246.Part II. Chemical and Microbiological Methods. $2^{\text {nd }}$ Ed., American Society of Agronomy, Madison, WI, USA.

Palta J P.1996. Role of calcium in plant responses to stresses: Linking basic research to the solution of practical problems. Journal of horticultural science31(1): 51-57.

Palta J P, Levitt J and Stadelmann E J.1977.Freezing injury in onion bulb cells.Plant Physiology60: 393-397.

Percival G C, Boyle C and Baired L.1999.The influence of calcium supplementation on the freezing tolerance of woody plants.Journal of Arboriculture25(6): 285291.

Piotrowska G and Kacperska A.1987.Relationship between ATP content desiccation-induced injuries in winter rape hypocotyls.Journal of Plant Physiology128:485-490.

Polisensky D H and Braam J.1996.Cold shock regulation of the Arabidopsis $\mathrm{TCH}$ genes 
and the effects of modulating intracellular calcium levels. Plant Physiology111:12711279.

Ruelland E and Zachowski A 2010. How plants sense temperature. Environmental and Experimental Botany69:225-232.

Sauter J J, Wisniewski M and Witt W.1996.Interrelationships between ultrastructure, sugar levels, and frost hardiness of ray parenchyma cells during frost acclimation and deacclimation in poplar (Populus x canadensisMoench 〈robusta〉) wood. Journal of Plant Physiology149:451-461.

Schaffer B, Whiley A W and Grane J H.1994.Mango, pp165-197.In- Handbook of Environmental Physiology of Fruit Crops.Vol.2. Sub-Tropical and Tropical Crops.Schaffer B and Anderson P C (Eds.).CRC Press Inc., Boca Raton, Florida. USA.

Siminovitch D.1981.Common and disparate elements in the processes of adaptation of herbaceous and woody plants to freezing: a perspective. Cryobiology18:166-185.

Singer S M, El-Tohamy W A, AbouHadid A F, Mokhart A H and Li P H.1996.Chilling and water stress injury in bean (Phaseolus vulgaris L.) seedlings reduced by pretreatment with $\mathrm{CaCl}_{2}$, mefluidide, $\mathrm{KCl}$ and $\mathrm{MgCl}_{2}$. Egyptian Journal of Horticulture 23(1):77-87.

Snedecor G W and Cochran W G.1980.Statistical Methods.pp401-403. $7^{\text {th }}$ Ed., Iowa state press, Ames, IA, USA.

Strand A, Foyer C H, Gustafsson P, Gardestrom
P, and Hurry V.2003.Altering flux through the sucrose biosynthesis pathway in transgenic Arabidopsis thaliana modifies photosynthetic acclimation at low temperatures and the development of freezing tolerance. Plant Cell Environment26:523-535.

Taiz L and Zeiger E.1998.Plant Physiology, pp735-736.2 ${ }^{\text {nd }}$ Ed.,Sinauer Associates Inc., Publishers, Sunderland, Massachusetts, USA.

Terzaghi W B, Fork D C, Berry J A, and Field C B.1989.Low and high temperature limits to PSII. A survey using transparinaric acid, delayed light emission and $F_{0}$ chlorophyll fluorescence.Plant Physiology91(4):14941500 .

Usadel B, Blasing O E, Gibon Y, Retzlaff K, Hoehne M, Gunther $M$ and Stitt M.2008.Multi-level genomic analysis of the response of transcripts, enzyme activities and metabolites in Arabidopsis rosettes to a progressive decrease of temperature in the non-freezing range.Plant Cell and Environment 31:518-547.

XinZ and Browse J.1998.Eskimo1 mutants of Arabisopsisare constitutively freezingtolerant. Proceedings of the National Academy of Sciences of the United States of America 95:7799-7804.

Zia M S,Salim M, Aslam M, Gill and Rahmatullah M A.1994.Effect of low temperature of irrigation water on rice growth and nutrient uptake.Journal of Agronomy and Crop Science 173(1):22-31.

\section{How to cite this article:}

Farouk M. Gadallah, Mohamed A. Seif El-Yazal, Gamal A. Abdel-Samad and Ali A. S. Sayed. 2020. Leakage Compositional Changes Accompanying to exposure of some Mango Cultivars to Low Temperature under Field Conditions. Int.J.Curr.Microbiol.App.Sci. 9(02): 1448-1463. doi: https://doi.org/10.20546/ijcmas.2020.902.168 